\title{
THE ROLE OF CYTOCIN IMBALANCE IN THE DEVELOPMENT OF MAN INFERTILITY
}

DOI: 10.36740/WLek202003123

\author{
Liliia S. Babinets, Bogdan 0. Migenko, Iryna O. Borovyk, Iryna M. Halabitska, Nataliia V. Lobanets, Orest O. Onyskiv \\ I. HORBACHEVSKY TERNOPIL NATIONAL MEDICAL UNIVERSITY, TERNOPIL, UKRAINE
}

\begin{abstract}
The aim: Study of the clinical and pathogenetic role of IL-17, IL-35 and their correlation in the development of infertility in men with chronic ureoprostatitis. Materials and methods: 82 male aged 20 to 40 were examined. The patients were divided into three groups: the first -10 practically healthy men, in which the levels of IL- 17 and IL-35 in semen were taken as normal; second - 33 infertile men with chronic urethroprostatitis; third - 39 fertile men with chronic urethroprostatitis. In addition to conventional clinical and laboratory (clinical blood and urine tests) studies, all men in semen were tested for IL-17 and IL-35 cytokine levels. Results: The levels of the studied cytokines were found to have opposite tendencies to shifts in the semen of men with chronic urethroprostatitis. The level of IL-17 in sperm increases and the level of IL-35 decreases. The IL-17/IL-35 index increases more strongly in men with impaired fertility.

Conclusions: Increas IL-17 concentrations, decreas IL-35 levels and increas their correlation may be an indicator of infertility in men with chronic ureoprostatitis. Determining the IL-17 / IL-35 correlation in general clinical practice will allow to single out a group of men with a high likelihood of developing infertility for follow-up and treatment by a doctor of family medicine.
\end{abstract}

KEYWORDS: urethroprostatitis, cytokines, male infertility

Wiad Lek. 2020;73(3):525-528

\section{INTRODUCTION}

The interest in reproductive health is caused by the emergence of numerous reports of a decrease in the quantitative and qualitative characteristics of semen, as well as an increase in cases of pathology of the male sexual sphere in the late XX - early XXI centuries, accompanied by the development of infertility $[1,2]$. The majority of patients cannot determine the cause of fertility decline, so the search for new diagnostic approaches remains relevant. The fine mechanisms of immune regulation of gametoid formation in men are being studied. It has been established that certain combinations of cytokine levels in the gonads create the optimal microenvironment for the maturation of generative cells [3]. Therefore, the violation of the concentration of certain cytokines in the gonads leads to a decrease in fertile function of men, as well as the development of autoimmune diseases [4].

During the course of the infectious process, the activation of the corresponding receptors and signal transduction pathways, accompanied by the release of biologically active substances such as proinflammatory cytokines [5]. Secreted proinflammatory cytokines are mediators of the host response to infection [6]. It is well known that the lymphocytic population of CD4 + T helper - (Th) cells can be distributed, in addition to T regulatory (Treg), Th9, Th17, Th22 and follicular (Tfh), also into two subpopulations of Th1 and Th2 on the basis of cytokines produced by them $[7,8,9]$. Th1 cells mainly secrete IL-2, IFN- $\gamma$, and
IL-12 interleukin, whereas Th 2 cells secrete IL-4, IL-5, and IL-10. Functionally, Th 1 cells mainly promote cell-mediated immunity and eliminate intracellular pathogens; Th2 cells are responsible for humoral immunity for protection against extracellular pathogens. The balance between these multifaceted cytokines, in particular between IL-12 and IL-4, determines the nature of the immune response [8]. IL-17 is a pro-inflammatory cytokine produced by the recently described Th17 cells, which play a critical role in the immune response against extracellular bacteria, as well as in the pathogenesis of some autoimmune disorders [9]. IL- 6 and TGF- $\beta$ are responsible for the generation of Th 17 cells. At the same time, IL-17 products are supported by IL1b, IL-15, IL-23, or TNF- $\alpha$. A number of researchers have obtained results confirming the possibility of stimulation of IL-17 by a factor inhibiting macrophage migration (MIF) $[10,11,12,13]$. The role of IL- 17 in the development of male infertility is poorly understood. IL-35 is part of the interleukin family that includes IL-12, IL-23, IL-27, and IL-35. IL-35 has an immunosuppressive effect on Th17 mediated through stimulation of Treg cells $[14,15,16,17]$. Under the influence of IL-35, CD4 + CD25 + T cells produce IL-10, and CD4 + CD25- T cells produce gamma interferon. In addition, IL-35 inhibits Th17 cell differentiation. Thus, IL-35 is an anti-inflammatory cytokine that inhibits the immune response $[18,19,20]$.

Changes in the proportion of cytokines (eg, IL-10: IL-12) are thought to be key in inhibiting immune defenses in the 
Table I. IL-17 and IL-35 levels in semen of men with chronic urethroprostatitis (Me $\pm[Q 25 ; 075]$ )

\begin{tabular}{ccccc}
\hline $\begin{array}{c}\text { Indicator of } \\
\text { immune status }\end{array}$ & $\begin{array}{c}\text { Norm } \\
\text { (control group men) }\end{array}$ & $\begin{array}{c}\text { Group I } \\
\text { (infertile men) }\end{array}$ & $\begin{array}{c}\text { Group II } \\
\text { (fertile men) }\end{array}$ & $\begin{array}{c}\text { P } \\
\text { IL-17, PG/ml }\end{array}$ \\
\hline IL-35, PG/ml & $52,2[11,4 ; 17,4]$ & $25,3[19,6 ; 29,9]^{* *}$ & $18,6[17,5 ; 22,2]^{*}$ & $<0,01$ \\
\hline IL17/IL35 & $0,27[0,21 ; 0,39]$ & $16,2[11,9 ; 24,4]^{* * *}$ & $38,9[26,5 ; 50,2]^{*}$ & $<0,01$ \\
\hline
\end{tabular}

Note: the reliability of the difference of indicators in comparison with the norm $\mathrm{P}:^{*}-<0,05,{ }^{* *}-<0,01,{ }^{* * *}-<0,001 ; \mathrm{P}$ is the significance of the difference between the groups.

Table II. Gradations of IL-17 and IL-35 content in semen of men with chronic urethroprostatitis

\begin{tabular}{|c|c|c|c|c|c|c|}
\hline \multirow{2}{*}{$\begin{array}{c}\text { Indicator of } \\
\text { immune status }\end{array}$} & \multirow[t]{2}{*}{ Fertility } & \multicolumn{5}{|c|}{ Grades of the indicator } \\
\hline & & $14-17$ & $18-21$ & $22-25$ & $26-29$ & 29 and more \\
\hline \multirow{3}{*}{ IL-17, PG/ml } & fertile & $18 / 46,1$ & $10 / 25,6$ & $7 / 18,0$ & $14 / 10,3$ & 0 \\
\hline & infertile & $3 / 9,1$ & $3 / 9,1$ & $11 / 33,3$ & $7 / 21,1$ & $9 / 27,3$ \\
\hline & norm & \multicolumn{5}{|c|}{$14,2 \pm 1,5$} \\
\hline \multirow{4}{*}{ IL-35, PG/ml } & & $11-21$ & $22-32$ & $33-43$ & $44-54$ & 55 and more \\
\hline & fertile & $4 / 10,2$ & $11 / 28,2$ & $1 / 2,6$ & $5 / 12,8$ & $18 / 46,2$ \\
\hline & infertile & $12 / 36,4$ & $11 / 33,3$ & $6 / 18,2$ & $4 / 12,1$ & 0 \\
\hline & norm & \multicolumn{5}{|c|}{$52,3 \pm 10,8$} \\
\hline \multirow{4}{*}{ IL17/IL35 } & & $0,2-0,8$ & $0,9-1,5$ & $1,6-2,2$ & $2,3-2,9$ & 3,0 and more \\
\hline & fertile & $21 / 53,8$ & $8 / 20,5$ & $10 / 30,8$ & 0 & 0 \\
\hline & infertile & 0 & $16 / 48,5$ & $12 / 36,4$ & $4 / 12,1$ & $1 / 3,0$ \\
\hline & norm & \multicolumn{5}{|c|}{$0,27 \pm 0,08$} \\
\hline
\end{tabular}

Note: in the numerator - the absolute number of patients, in the denominator - $\%$ to the number of patients examined

lower parts of the genital tract, inhibiting cell-mediated immune responses and immunosuppression [21,22,23].

Based on the previously proven role of IL-17 as a major mediator of the development of chronic inflammation and autoimmune damage, and IL-35 as a cytokine, which in turn inhibits the inflammatory process and the development of autosensitization, we were tasked with investigating the IL-17 / IL-35 ratio in sperm men with chronic urethroprostatitis depending on fertile function.

\section{THE AIM}

Study of the clinical and pathogenetic role of IL-17, IL-35 and their correlation in the development of infertility in men with chronic ureoprostatitis.

\section{MATERIALS AND METHODS}

There were 82 men aged 20 to 40 under our supervision. All patients gave informed written consent to participate in the study, which was approved by the Bioethics Committee of Ternopil NMU Ministry of Health of Ukraine. The researches were carried out in accordance with ethical norms and moral and legal requirements of the order of the Ministry of Health of Ukraine No. 281 of 01.11.2000. The patients were divided into three groups: the first group consisted of 10 healthy men whose IL-17 and IL-35 levels in semen were normal; the second - 33 infertile men with chronic urethroprostatitis; third - 39 fertile men with chronic urethroprostatitis. In addition to conventional clinical and laboratory (clinical blood and urine) studies, all men in semen were tested for IL-17 and IL-35 cytokine levels. In patients with chronic urethroprostatitis, the presence of sexually transmitted infections has been confirmed by the polymerase chain reaction method. The duration of the disease ranged from 1 to 10 years.

All patients were examined clinically, including examination and palpation of the penis, scrotum, and prostate, and a history was carefully collected. All patients donated semen for analysis. On the eve of the assay, no ejaculation had to occur within 4-5 days. The semen was analyzed half an hour after the ejaculation and according to the WHO instruction [24]. They took into account the sperm concentration, the $\mathrm{pH}$ of the semen, the leukocyte content. The study did not include patients with leukospermia. The semen was centrifuged before analysis at 1,700 rpm to separate the sperm from the family plasma. IL-17 and IL-35 cytokine concentrations in seminal plasma [25] were determined by the enzyme immunoassay using a STAT-FAX-303 PLUS analyzer (USA) at $492 \mathrm{~nm}$ and the Panomics Quantitative Assays test system by "Affymetrix» (USA). Control values for the concentrations of the above 
cytokines were obtained in a study of 10 fertile men without clinical signs of disease, similar in composition to age.

Statistical analysis of the obtained results was performed in the environment of the licensed statistical package of the MedStat program [26]. At the same time, the Shapiro-Wilk test was used to test the indicators for normal distribution. Since all the data belonged to a distribution other than normal, they are given in the form Me [Q25; Q75]. The median was calculated, $25 \%$ quartile, $75 \%$ quartile. The criterion $\chi 2$, the two-sided critical region, was used to compare the indicators. To compare the mean values of the trait for two independent samples, Fisher's angular transformation method was used, taking into account the Yeats' correction. Significant was considered the difference at $p<0.01$. Kendall's paired correlation coefficient $-\tau$ was calculated to analyze the presence and strength of the link.

\section{RESULTS AND DISCUSSION}

Studies have shown that the majority of men with chronic prostatitis complicated with infertility have detected shifts in the concentration of IL-17 and IL-35 in semen.

An immunological study showed (Table I) that the examined patients with infertility showed a significant decrease in IL-35 family plasma $(16.2 \pm 3.7 \mathrm{pg} / \mathrm{ml}, \mathrm{p}<0.001)$ on the background of a significant increase in IL-17 concentration $(25.3 \pm 2.4 \mathrm{pg} / \mathrm{ml}, \mathrm{p}<0.01)$. In fertile men, these indicators also had a significant difference from the normative indicators, but the multiplicity of the difference was smaller. Thus, for infertile men, the multiplicity of difference for IL-17 and IL-35 was respectively 1.8 and 3.2. For fertile men, the multiplicity of difference was 1.2 and 1.4, respectively. The study of the IL-17 / IL-35 index showed its increase in men with chronic uretroprostatitis, complicated by infertility, to $1.56 \pm 0.51, \mathrm{p}<0.001$, which is 3.3 times higher than in men with chronic urethroprostatitis with preserved fertility.

A study of the gradations of IL- 17 and IL- 35 cytokine levels in the semen of men with chronic urethroprostatitis depending on fertile function showed that in patients with preserved fertility $46.1 \%$ for IL-17 and $59.0 \%$ for IL- 35 their values did not go beyond the normative ones (Table II).

In infertile men, cytokines IL-17 and IL-35 in the semen of men with chronic urethroprostatitis remained within the normative range of only $9.1 \%$ and $12.1 \%$, respectively. As for the immunological index IL-17 / IL-35, in infertile men with chronic urethroprostatitis in no patient this ratio did not acquire normative values. At the same time in fertile men with chronic urethroprostatitis, this ratio was within the normative values in almost half of the patients. Therefore, it was considered appropriate to study the IL-17 / IL-35 ratio, which may be informative enough to determine fertile function in men with both chronic urethral prostatitis and other urogenital tract lesions.

Therefore, it was found that the levels of cytokines under study had opposite tendencies to shifts in semen of men with chronic urethroprostatitis. The level of IL-17 in sperm increases and the level of IL-35 decreases. The IL-17 / IL-35 index is statistically significantly higher in men with impaired fertility.

Determination of IL-17 and IL-35 levels may be a biomarker for chronic inflammation of the urogenital tract in men in sperm serum. During the development of infertility in the sperm, the concentration of IL-17 increases and the concentration of IL-35 sharply decreases. Disruption of cytokinogenesis in men with chronic urethroprostatitis leads to the development of infertility. The index of IL-17/IL-35 may serve as a marker of infertility.

\section{CONCLUSIONS}

1. The biomarker of chronic inflammation of the urogenital tract in men with semen may be to determine the levels of IL-17 and IL-35.

2. During the development of infertility in sperm, the concentration of IL-17 increases and the concentration of IL-35 sharply decreases.

3. Impairment of cytokinogenesis in men with chronic urethroprostatitis is associated with the development of infertility. The index of IL-17 / IL-35 may serve as a marker of infertility.

4. Determining the IL-17 / IL-35 correlation in general clinical practice will allow to single out a group of men with a high likelihood of developing infertility for follow-up and treatment by a doctor of family medicine.

\section{REFERENCES}

1. World Health Organization. A vision for primery health care in the 21st century: World Health Organization and the United Nations Children's Fund (UNICEF), 2018.64 p.

2. Comhaire F, Van Waeleghem K, De Clercq N. Declining sperm quality in European men. Andrologia. 1996;28:300-301.

3. Fraczek M, Kurpisz M. Cytokines in the male reproductive tract and their role in infertility disorders. Journal of Reproductive Immunology. 2015;108:98-104.

4. Havrylyuk A, Chopyak V, Boyko Y et al. Clinical immunology Cytokines in the blood and semen of infertile patients. Cent. Eur. J. Immunol. 2015;40(3):337-344.

5. Nikitin 0.D. Patohenetychne obgruntuvannya likuvannya ta profilaktyka zakhvoryuvan' u cholovikiv, shcho pryzvodyat' do podruzhn'oho bezpliddya: dys. d-ra medychnykh nauk: 14.01.06/NMU imeni 0.0.Bohomol'tsya.K., 2017.349 s.

6. Jiang L, Zheng T, Huang J et al. Association of semen cytokines with reactive oxygen species and histone transition abnormalities. J Assist Reprod Genet. 2016;33(9):1239-46. doi: 10.1007/s10815-016-0756-7.

7. Hirahara K, Nakayama T. CD4+T-cell subsets in inflammatory diseases: beyond the Th1/Th2 paradigm. Int Immunol. 2016;28(4):163-71. doi: 10.1093/intimm/dxw006.

8. Raphael I, Nalawade S, Eagar T, Forsthuber T.G. T cell subsets and their signature cytokines in autoimmune and inflammatory diseases. Cytokine. 2015;74(1):5-17. doi: 10.1016/ j.cyto.2014.09.011.

9. Hamza T, Barnett J, Li B. Interleukin 12 a Key Immunoregulatory Cytokine in Infection Applications. Int J Mol Sci. 2010;11(3):789-806. doi: 10.3390/ijms11030789.

10. Aujla S, Dubin P, Kolls J. Th17 cells and mucosal host defense. Semin Immunol. 2007; 19(6):377-82. 
11. Qian L. The relationship between IL-17 and male infertility: semen analysis. African J Microbiol Res. 2012;6(27):5672-7.

12. Stojanović I, Cvjetićanin T, Lazaroski S et al. Macrophage migration inhibitory factor stimulates interleukin-17 expression and production in lymph node cells. Immunology. 2009;126(1):74-83. doi: 10.1111/ j.1365-2567.2008.02879.x.

13. Qu N. et al. Pivotal roles of T-helper 17-related cytokines, IL-17, IL-22, and IL-23, in inflammatory diseases. Clin Dev Immunol. 2013;293-306. doi: 10.1155/2013/968549.

14. Wang R, Yu C, Dambuza I, Mahdi R et al. Interleukin-35 induces regulatory $B$ cells that suppress autoimmune disease. Nat Med. 2014; 20:633-641.

15. Shen P, Roch T, Lampropoulou V et al. IL-35-producing B cells are critical regulators of immunity during autoimmune and infectious diseases. Nature. 2014; 507:366-370.

16. Collison L, ChaturvediV, Henderson A et al. IL-35-mediated induction of a potent regulatory T cell population. bNat Immunol. 2010; 11(12):1093101. doi: $10.1038 /$ ni.1952.

17. Niedbala W, Wei X, Cai B et al. IL-35 is a novel cytokine with therapeutic effects against collagen-induced arthritis through the expansion of regulatory T cells and suppression of Th17 cells. Eur. J. Immunol. 2007; 37:3021-3029.

18. Collison L, Workman C, KuoT tet al. The inhibitory cytokine IL-35 contributes to regulatory T-cell function. Nature. 2007; 450(7169):566-569.

19. Lin Y, Huang Y, Lu Z et al. Decreased plasma IL-35 levels are related to the left ventricular ejection fraction in coronary artery diseases. Plos One. 2012; 7(12):52490. doi: 10.1371 / Journal. pone. 0052490.

20. Tsiporenko S. Study of effect of glutoxim on the production of cytokines IL-12 family (IL-12, IL-23, IL-27, IL-35) in semen and serum of male patients with oligosymptomatic forms of chronic urogenital infection. East European Scientific Journal. 2018; 1(29):25-29.

21. Louw-du Toit R, Hapgood J, Africander D. Medroxyprogesterone acetate differentially regulates interleukin (IL)-12 and IL-10 in a human ectocervical epithelial cell line in a glucocorticoid receptor (GR)-dependent manner. J Biol Chem. 2014; 289(45):31136-49.

22. S. Tsiporenko, L. Matyucha, The research of medical and social factors of the risk of reproductive health of men by family doctor. Wiad. Lek. 2018;71(2):285-290.

23. Bromfield J. Seminal fluid and reproduction: much more than previously thought. J Assist Reprod Genet. 2014; 31(6):627-36.

24. WHO laboratory manual for the examination of human sperm and semem-cervical mucus interaction. WH0, 4-th edn.: Cambridge universiti press.1999; p. 128.
25. Gruschwitz M, Brezinschek R, Brezinschek H. Cytokine levels in the seminal plasma of infertile males. J. Androl.1996; 17:158 -163.

26. Lyakh YU, Gur'yanov V. Osnovy komp'yuternoy biostatistiki: analiz informatsii v biologii, meditsine i farmatsii statisticheskim paketom MedStat. Donetsk. - 2004; p. 212.

Research topic: 0118U000361, "Comprehensive approach to the control of symptoms, direct and distant prognosis in conditions of comorbid pathology in the clinic of internal diseases and the practice of a family medicine."

\section{ORCID and contributionship:}

Liliia S. Babinets - 0000-0002-0560-1943 A,B,C,D,E,F

Bogdan O. Migenko - 0000-0003-2192-7238 A,C,D,E

Iryna O. Borovyk - 0000-0003-0114-2935 A,B,E,F

Iryna M. Halabitska - 0000-0002-9028-7230 A,B,C,D,E,E.

Nataliia V. Lobanets - 0000-0001-6711-9338 ${ }^{A, B}$

Orest O. Onyskiv - 0000-0002-0192-7647 A,E,F

\section{Conflict of interest:}

The Authors declare no conflict of interest.

\section{CORRESPONDING AUTHOR}

Liliia S. Babinets

I. Horbachevsky Ternopil National Medical University

Kupchynsky 14 Str., Ternopil, Ukraine, 46400;

tel: +380673520743

e-mail: lilyababinets@gmail.com

Received: 17.01 .2020

Accepted: 05.03 .2020

A - Work concept and design, B - Data collection and analysis, C - Responsibility for statistical analysis, D-Writing the article, $\mathbf{E}$-Critical review, $\mathbf{F}$ - Final approval of the article 